JADWIGA TURKIEWICZ*, JAN SiKORA*

\title{
SOUND ABSORBING MATERIALS FROM RECYCLED RUBBER PRODUCTS
}

\begin{abstract}
This paper concerns the results of comparative research into the acoustical properties of rubber granulates derived from the recycling of conveyor belts production waste. In the process of recycling it is possible to obtain pure granulated rubber and forms contaminated with cotton fibres with a predominance of rubber grains or of cotton fabric. Rubber granulate in the contaminated form is characterized by sound-absorbing properties similar to those of the average-quality mineral wool and other fibrous materials. It can be used as the core of sound-absorbing panels in anti-noise protections. The research results can be used both in the design of acoustical protection as well as in the course of the recycling process of other waste products for obtaining materials with sound absorbing properties.
\end{abstract}

Keywords: sound absorption coefficient, sound absorbing materials, noise control

\section{MATERIAEY DŹWIĘKOCHŁONNE Z RECYKLINGU WYROBÓW GUMOWYCH}

$W$ artykule przedstawiono wyniki badań porównawczych własności dźwiękochłonnych granulatu gumowego uzyskanego w wyniku recyklingu odpadów produkcyjnych taśm transporterowych. W procesie recyklingu można uzyskać czysty granulat gumowy oraz postacie zanieczyszczone wtóknem bawetnianym z przewaga ziaren gumowych lub tkaniny bawetnianej. Granulat gumowy w postaci zanieczyszczonej charakteryzuje się własnościami dźwiękochłonnymi zblizonymi do własności przeciętnej jakościowo wetny mineralnej i innych materiałów włóknistych. Może być stosowany jako rdzeń dźwiękochłonny w przegrodach warstwowych zabezpieczeń przeciwhałasowych. Przedstawione wyniki badań mogą być wykorzystane zarówno w projektowaniu zabezpieczeń akustycznych, jak $i$ w procesie recyklingu innych zużytych wyrobów pod kątem uzyskiwania materiałów o właściwościach dźwiękochłonnych.

Słowa kluczowe: współczynnik pochłaniania dźwięku, materiały dźwiękochłonne, zwalczanie hałasu

\section{INTRODUCTION}

In material and design solutions of vibroacoustical safeguards reducing noise generated by industrial, transportation and municipal sources, sound absorbing materials in the form of granulates obtained from recycled wastes and worn out rubber products may be efficiently used. New studies prove that materials acquired from the recycling of decommissioned conveyor belts, car tyres and production wastes containing cotton separators may be particularly useful.

Rubber layers made of solid and porous rubber have been taken into account for many years in the design and selection of sound-insulating barriers and sound absorbing materials applied in them. Carried out research aimed at determining sound absorbing properties of granular materials and potentials for using them in sound absorbing and insulating barriers and have proven usability of e.g. rubber granulates (Sikora 2007a,b, 2011 Sikora and Turkiewicz 2007, 2010, 2012). Rubber granulates have good sound absorbing properties and may be used as sound absorbing cores in double-wall barriers. Same as granulates made of other natural and plastic materials, rubber granulates are characteristic of narrow-band sound absorption (Swift et al. 1999, Sikora and Turkiewicz 2010). This is a certain drawback. Materials of this type cannot replace mineral wool, which has broad-band characteristics. Whereas, this sound absorption characteristic is ensured by granulates obtained from recycling of worn out conveyor belts, called fabric-rubber and rubber granulates.

\section{RUBBER GRANULATE MATERIALS}

For many years the authors of the paper have been involved in acoustical studies on new materials, which may be useful in the design of vibroacoustical safeguards including: sound absorbing and insulating housings, building partitions, integrated housings designed for machines requiring continuous and direct maintenance and acoustic panels for the construction of acoustic screens, and will be competitive for currently used ones. Obtained positive results of the research into sound absorbing properties of rubber granulates have become an inspiration for acoustical studies on granulates received from the recycling of conveyor belt production wastes. Special attention has been paid to acoustical properties of rubber granulates not entirely freed from cotton fibre, and also recovered fibre itself slightly contaminated with fine rubber grain. Preliminary examinations of rubber granulates with cotton fibre impurities have proven that sound absorption of these materials has broad-band characteristics, much like that of mineral wool, which to some extent constitutes a model of broad-band sound absorbing material employed in vibroacoustical safeguards.

* AGH University of Science and Technology, Department of Mechanics and Vibroacoustics, Faculty of Mechanical Engineering and Robotics, Krakow, Poland, turkiewi@imir.agh.edu.pl, jsikora@agh.edu.pl 


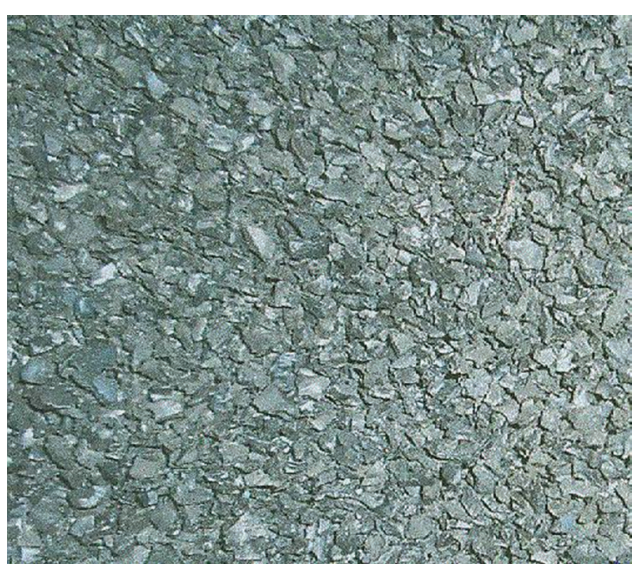

Fig. 1. Rubber granulate: volumetric density: $458 \mathrm{~kg} / \mathrm{m}^{3}$, grain size: $2 \times 4 \mathrm{~mm}$, grain shape: irregular flakes, fine-grained type

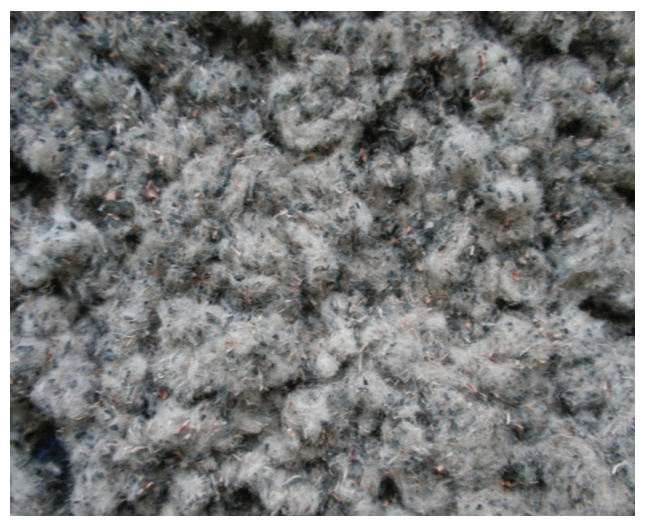

Fig. 2. Fabric-rubber granulate: volumetric density: $340 \mathrm{~kg} / \mathrm{m}^{3}$, rubber granulate contaminated with cotton fibre floccules, grain size: $2 \times 4 \mathrm{~mm}$

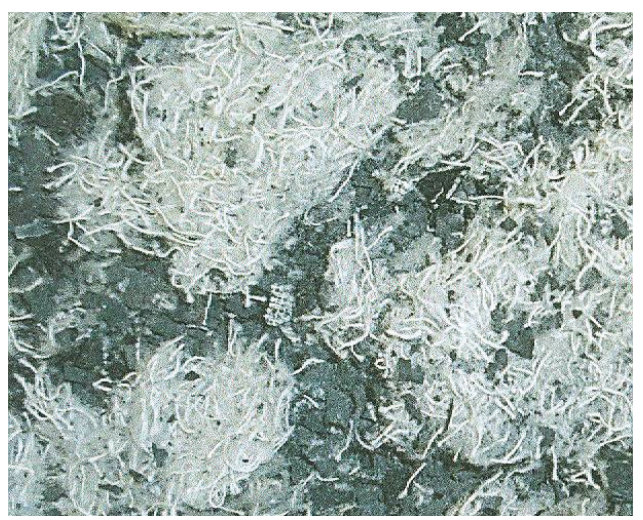

Fig. 3. 'Lamin' fabric granulate: volumetric density: $40 \mathrm{~kg} / \mathrm{m}^{3}$, cotton fibres shaken to obtain wadding form, slightly contaminated with rubber granulate, grain size: $2 \times 2 \mathrm{~mm}$

Rubber granulates are formed as a result of rubber waste shredding: conveyor belts, tyre treads, protectors, membranes, gaskets, flashes, etc. They have the form of grains with regular or irregular shapes and are black. These materials with different grain sizes have good sound absorbing properties due to layer structure, much like porous or fibrous, in which sound energy is absorbed through penetration into formed pores and air capillaries.

The process of shredding rubber production wastes, e.g. conveyor belts (edge trimming residues) allows obtaining rubber granulate in three forms: rubber granulate (after cotton fabric removal), fabric-rubber granulate (contaminated with cotton fibre) and fabric granulate (cotton fibre separated from rubber grains shaken to receive wadding). Figures 1-3 show all three of the above-mentioned granulate forms, where sound absorbing characteristics have been determined for comparison.

\section{EXPERIMENTAL STAND}

Examinations of physical sound absorption coefficient $\alpha_{f}$ (at perpendicular sound wave incidence onto the examined material sample surface) have been carried out for five thickness values $(10,20,30,40$ and $50 \mathrm{~mm})$ of each of the three rubber granulate forms. An impedance tube (Kundt's tube) has been used to carry out the experiment, which allows for determining a sound absorption coefficient value using the method based on standing wave coefficient (PN-EN ISO 10534-1:2004, Sikora 2011). This method is very useful for carried out studies, and also for preliminary examinations, since it makes it possible to determine the suitability of new

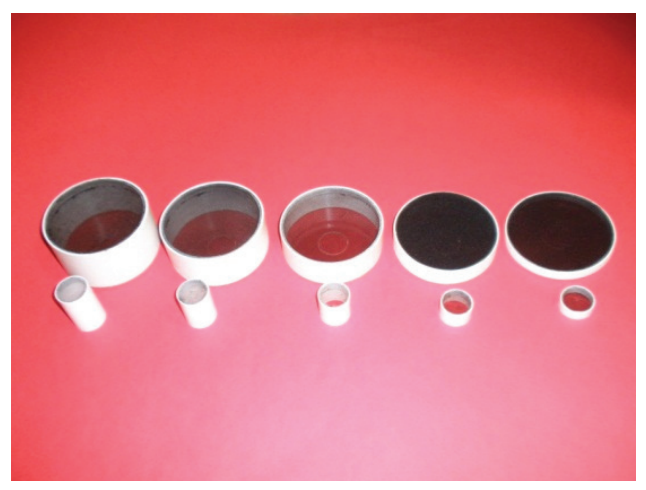

Fig. 4. A set of sleeves to examine sound absorbing properties for five layer thickness values $(10,20,30,40,50 \mathrm{~mm})$

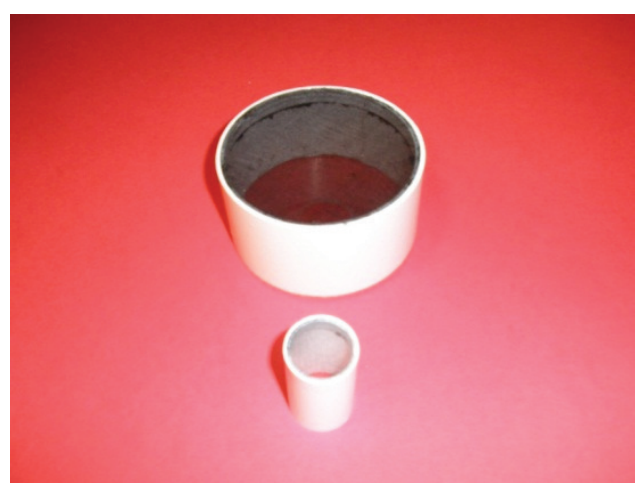

Fig. 5. Sleeves, 30 and $100 \mathrm{~mm}$ in diameter, to examine $50 \mathrm{~mm}-$ -thick material layer 
materials (or materials not examined yet) from the point of view of their sound absorbing properties. Only a small amount of examined material is needed to perform acoustical tests using this method: 2 samples (disks), 30 and 100 $\mathrm{mm}$ in diameter, which is very important from an economic point of view - the relatively low cost of preparing material samples for laboratory examination.

To examine materials of this type, it has been necessary to put them in special plastic sleeves (figs. 4-5), on one side closed with solid walls, and on the other (the side of the sound wave incidence onto the examined sample surface) - with a flexible thin unwoven fabric characterised by very small stitches, made specifically to examine materials not having hard structure.

\section{RESULTS OF MEASUREMENTS AND ANALYSIS}

Results of experimental studies on sound absorbing properties of fabric granulate (fig. 3) have been compiled for comparative purposes with the results of previously completed studies (Sikora and Turkiewicz 2012) on granulates (fig. 1, fig. 2). Sound absorbing properties of rubber granulate in three forms obtained from the recycling of worn out conveyor belts are shown graphically (figs. 6-8) and in tables (tabs 1-3).

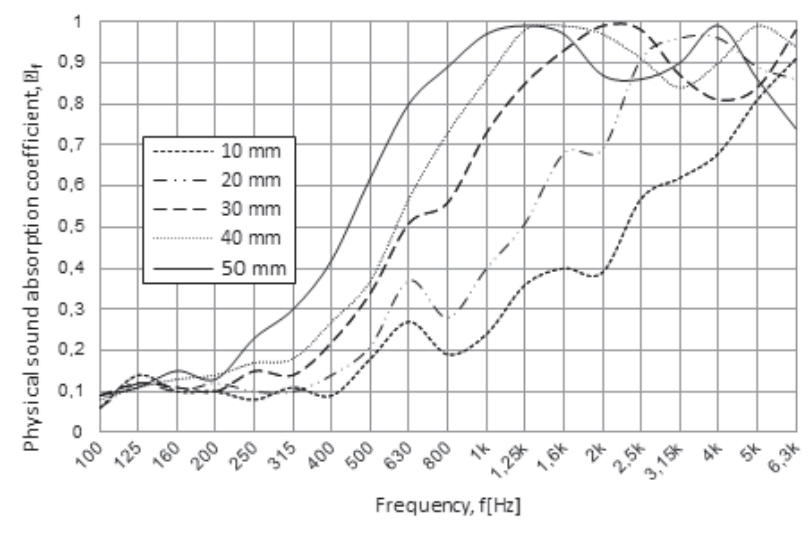

Fig. 6. Comparison of sound absorption characteristics for five thicknesses of 'lamin' fabric granulate

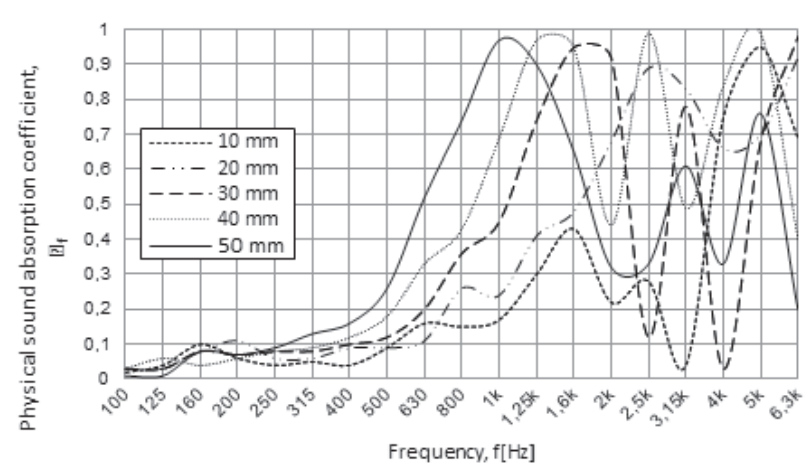

Fig. 7. Comparison of sound absorption characteristics for five thicknesses of rubber granulate layer

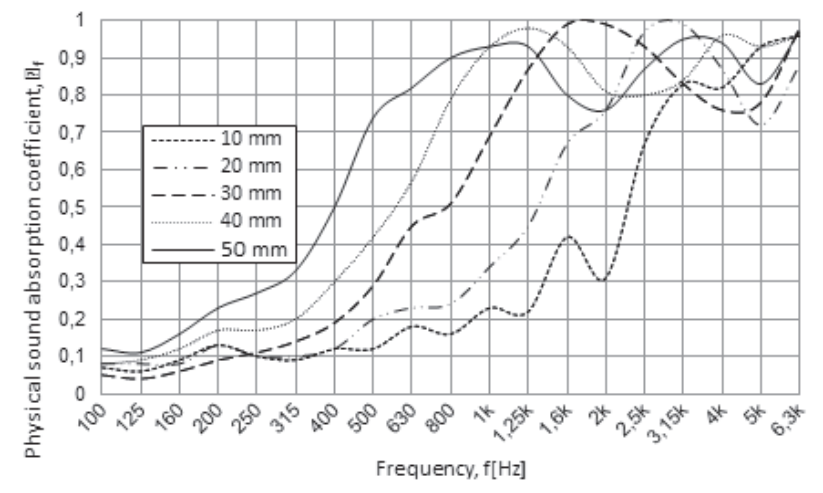

Fig. 8. Comparison of sound absorption characteristics for five thicknesses of fabric-rubber granulate layer

\section{Table 1}

Values of physical sound absorption coefficient $\alpha_{f}$ for 'lamin' fabric granulate in five layer thicknesses

\begin{tabular}{|c|c|c|c|c|c|c|c|}
\hline \multirow{2}{*}{\multicolumn{3}{|c|}{$\begin{array}{c}\text { 'Lamin' fabric } \\
\text { granulate }\end{array}$}} & \multicolumn{5}{|c|}{ Layer thickness [mm] } \\
\hline & & & \multirow{2}{*}{$\begin{array}{c}10 \\
0.06\end{array}$} & \multirow{2}{*}{$\begin{array}{c}20 \\
0.06\end{array}$} & \multirow{2}{*}{$\begin{array}{c}30 \\
0.09\end{array}$} & \multirow{2}{*}{$\begin{array}{c}40 \\
0.08\end{array}$} & \multirow{2}{*}{$\begin{array}{c}50 \\
0.09\end{array}$} \\
\hline \multirow{19}{*}{ 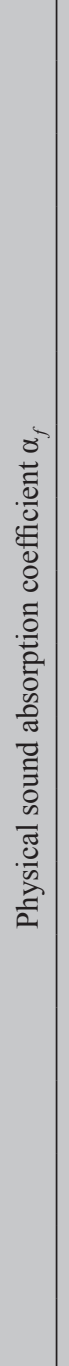 } & \multirow{19}{*}{ 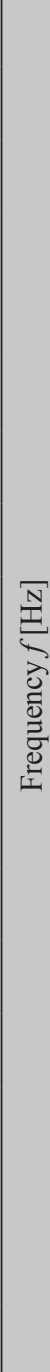 } & 100 & & & & & \\
\hline & & 125 & 0.14 & 0.12 & 0.12 & 0.11 & 0.11 \\
\hline & & 160 & 0.10 & 0.10 & 0.11 & 0.13 & 0.15 \\
\hline & & 200 & 0.10 & 0.12 & 0.10 & 0.14 & 0.13 \\
\hline & & 250 & 0.08 & 0.10 & 0.15 & 0.17 & 0.23 \\
\hline & & 315 & 0.11 & 0.10 & 0.14 & 0.18 & 0.30 \\
\hline & & 400 & 0.09 & 0.14 & 0.22 & 0.27 & 0.42 \\
\hline & & 500 & 0.18 & 0.21 & 0.34 & 0.37 & 0.62 \\
\hline & & 630 & 0.27 & 0.37 & 0.51 & 0.57 & 0.80 \\
\hline & & 800 & 0.19 & 0.28 & 0.56 & 0.73 & 0.89 \\
\hline & & 1000 & 0.24 & 0.40 & 0.73 & 0.86 & 0.97 \\
\hline & & 1250 & 0.36 & 0.51 & 0.85 & 0.98 & 0.99 \\
\hline & & 1600 & 0.40 & 0.68 & 0.93 & 0.99 & 0.97 \\
\hline & & 2000 & 0.39 & 0.69 & 0.99 & 0.97 & 0.87 \\
\hline & & 2500 & 0.57 & 0.91 & 0.98 & 0.91 & 0.86 \\
\hline & & 3150 & 0.62 & 0.96 & 0.87 & 0.84 & 0.90 \\
\hline & & 4000 & 0.68 & 0.96 & 0.81 & 0.90 & 0.99 \\
\hline & & 5000 & 0.81 & 0.89 & 0.84 & 0.99 & 0.86 \\
\hline & & 6300 & 0.91 & 0.86 & 0.98 & 0.94 & 0.96 \\
\hline \multicolumn{3}{|c|}{$\boldsymbol{\alpha}_{\text {avg }}$} & 0.33 & 0.45 & 0.54 & 0.59 & 0.64 \\
\hline
\end{tabular}




\section{Table 2}

Values of physical sound absorption coefficient $\alpha_{f}$ for rubber granulate in five layer thicknesses

\begin{tabular}{|c|c|c|c|c|c|c|c|}
\hline \multirow{2}{*}{\multicolumn{3}{|c|}{$\begin{array}{l}\text { Rubber granu- } \\
\text { late }\end{array}$}} & \multicolumn{5}{|c|}{ Layer thickness [mm] } \\
\hline & & & \multirow{2}{*}{$\frac{10}{0.02}$} & \multirow{2}{*}{$\frac{20}{0.03}$} & \multirow{2}{*}{$\frac{30}{0.03}$} & \multirow{2}{*}{$\frac{40}{0.03}$} & \multirow{2}{*}{$\frac{50}{0.01}$} \\
\hline \multirow{19}{*}{ 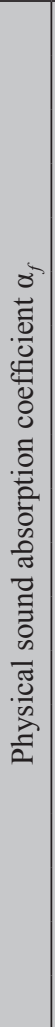 } & \multirow{19}{*}{ 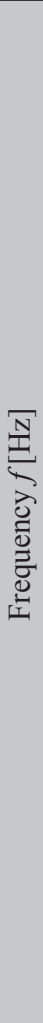 } & 100 & & & & & \\
\hline & & 125 & 0.04 & 0.03 & 0.03 & 0.06 & 0.01 \\
\hline & & 160 & 0.10 & 0.08 & 0.08 & 0.04 & 0.08 \\
\hline & & 200 & 0.06 & 0.11 & 0.07 & 0.06 & 0.07 \\
\hline & & 250 & 0.04 & 0.06 & 0.08 & 0.08 & 0.09 \\
\hline & & 315 & 0.05 & 0.06 & 0.08 & 0.08 & 0.13 \\
\hline & & 400 & 0.04 & 0.09 & 0.10 & 0.12 & 0.16 \\
\hline & & 500 & 0.09 & 0.09 & 0.12 & 0.18 & 0.26 \\
\hline & & 630 & 0.16 & 0.11 & 0.20 & 0.33 & 0.52 \\
\hline & & 800 & 0.15 & 0.26 & 0.36 & 0.43 & 0.74 \\
\hline & & 1000 & 0.17 & 0.24 & 0.45 & 0.69 & 0.97 \\
\hline & & 1250 & 0.30 & 0.41 & 0.74 & 0.97 & 0.90 \\
\hline & & 1600 & 0.43 & 0.48 & 0.95 & 0.95 & 0.65 \\
\hline & & 2000 & 0.22 & 0.68 & 0.92 & 0.44 & 0.32 \\
\hline & & 2500 & 0.28 & 0.89 & 0.12 & 0.99 & 0.33 \\
\hline & & 3150 & 0.04 & 0.83 & 0.78 & 0.49 & 0.61 \\
\hline & & 4000 & 0.75 & 0.66 & 0.03 & 0.84 & 0.33 \\
\hline & & 5000 & 0.95 & 0.70 & 0.68 & 0.99 & 0.76 \\
\hline & & 6300 & 0.69 & 0.92 & 0.98 & 0.40 & 0.20 \\
\hline \multicolumn{3}{|c|}{$\boldsymbol{\alpha}_{\text {avg }}$} & 0.24 & 0.35 & 0.36 & 0.38 & 0.38 \\
\hline
\end{tabular}

\section{FINAL REMARKS}

A comparison of experimental examination results for 'lamin' fabric granulate with the other two forms of rubber granulate obtained from the recycling of worn out conveyor belts allows carrying out the following acoustical evaluation useful for designers of systems protecting against noise and companies engaged in the recycling of rubber and production wastes:

- sound absorption characteristics of 'lamin' fabric granulate allow (same as in case of fabric-rubber granulate) counting it among broad-band sound absorbing materials. Absorption characteristic of this material is much like that of mineral wool;

- in 'lamin' fabric and fabric-rubber granulates, a clear impact of layer thickness on sound absorption is observed. Increasing layer thickness results in growing average value of absorption coefficient;

- same as in the case of granulates of other natural and plastic materials, 'pure' rubber granulate has narrow-band sound absorption characteristics. Therefore, there is no increase in the average absorption coefficient value, however, as layer thickness increases, resonance frequency (for which highest sound absorption occurs) shifts from high to medium frequencies.

\section{Table 3}

Values of physical sound absorption coefficient $\alpha_{f}$ for fabric-rubber granulate in five layer thicknesses

\begin{tabular}{|c|c|c|c|c|c|c|c|}
\hline \multirow{2}{*}{\multicolumn{3}{|c|}{$\begin{array}{l}\text { Fabric-rubber } \\
\text { granulate }\end{array}$}} & \multicolumn{5}{|c|}{ Layer thickness [mm] } \\
\hline & & & \multirow{2}{*}{$\frac{10}{0.07}$} & \multirow{2}{*}{$\frac{20}{0.08}$} & \multirow{2}{*}{$\frac{30}{0.05}$} & \multirow{2}{*}{$\frac{40}{0.08}$} & \multirow{2}{*}{$\frac{50}{0.12}$} \\
\hline \multirow{19}{*}{ 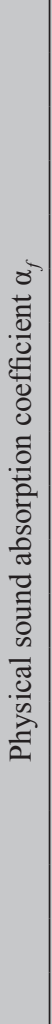 } & \multirow{19}{*}{ 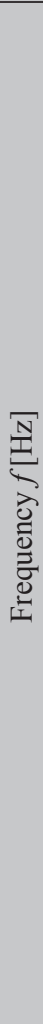 } & 100 & & & & & \\
\hline & & 125 & 0.06 & 0.08 & 0.04 & 0.09 & 0.11 \\
\hline & & 160 & 0.09 & 0.08 & 0.06 & 0.12 & 0.16 \\
\hline & & 200 & 0.13 & 0.13 & 0.09 & 0.17 & 0.23 \\
\hline & & 250 & 0.10 & 0.10 & 0.11 & 0.17 & 0.27 \\
\hline & & 315 & 0.09 & 0.10 & 0.14 & 0.20 & 0.33 \\
\hline & & 400 & 0.12 & 0.12 & 0.19 & 0.30 & 0.50 \\
\hline & & 500 & 0.12 & 0.20 & 0.29 & 0.42 & 0.74 \\
\hline & & 630 & 0.18 & 0.23 & 0.45 & 0.57 & 0.82 \\
\hline & & 800 & 0.16 & 0.24 & 0.51 & 0.979 & 0.90 \\
\hline & & 1000 & 0.23 & 0.34 & 0.69 & 0.93 & 0.93 \\
\hline & & 1250 & 0.22 & 0.45 & 0.87 & 0.98 & 0.93 \\
\hline & & 1600 & 0.42 & 0.67 & 0.99 & 0.93 & 0.80 \\
\hline & & 2000 & 0.31 & 0.76 & 0.99 & 0.81 & 0.76 \\
\hline & & 2500 & 0.67 & 0.97 & 0.93 & 0.80 & 0.87 \\
\hline & & 3150 & 0.83 & 0.99 & 0.83 & 0.84 & 0.95 \\
\hline & & 4000 & 0.82 & 0.87 & 0.76 & 0.96 & 0.94 \\
\hline & & 5000 & 0.93 & 0.72 & 0.78 & 0.93 & 0.83 \\
\hline & & 6300 & 0.96 & 0.88 & 0.98 & 0.96 & 0.97 \\
\hline \multicolumn{3}{|c|}{$\boldsymbol{\alpha}_{\text {avg }}$} & 0.34 & 0.42 & 0.51 & 0.38 & 0.64 \\
\hline
\end{tabular}

Completed experimental studies on rubber granulates obtained from the recycling of worn out rubber products prove that apart from refined rubber granulates it is possible to successfully use other recycling products - granulates with an admixture of cotton fibre and fibre itself in form of wadding, with a structure much like that of mineral and glass wool. Likeness to materials conventionally used in systems protecting against noise allows expecting possibility of using these rubber recycling products in laminar barriers as sound absorbing cores and linings. This conclusion also applies to other materials - mineral wool 'granulates'. Research results may also be useful for companies engaged in recycling of other worn out materials and products, which contain recoverable cotton fibres and other that after shredding may get fibrous structure constituting potential sound absorbing material. Of course, authors realise that any given material requires further processing before being used as sound absorbing product. Nevertheless, already in its preliminary form, it may be applied to wall elements of prototype systems protecting against noise, working as sound absorbing core replacing conventional sound absorbing materials. 


\section{Aknowledgements}

The paper has been prepared as a part of implementation of a development project no. II.B.12 (2011-2013): 'New material solutions for laminar barriers in the design of vibroacoustic safeguards for machines and equipment', constituting one of the tasks of a multiannual programme 'Improvement of safety and working conditions' coordinated by CIOP - PIB in Warsaw.

\section{References}

PN-EN ISO 10534-1:2004, Akustyka określenie współczynnika pochłaniania dźwięku i impedancji akustycznej $w$ rurach impedancyjnych. Część 1: Metoda wykorzystująca wspótczynnik fal stojących.
Sikora J. 2007a, Sound absorbing properties of granular materials. Izolacje, No. 9, pp. 26-29.

Sikora J. 2007b, Investigations of sound absorption coefficient of granular materials. Technical Journal - Mechanics, No. 11(104), pp. 79-88.

Sikora J. 2011, Warstwy gumowe w rozwiazaniach zabezpieczeń wibroakustycznych. Wydawnictwa AGH, Kraków.

Sikora J., Turkiewicz J. 2007, Double-wall barriers with sound absorbing cores made of granular materials. Izolacje, No. 10, pp. 28-33.

Sikora J., Turkiewicz J. 2010, Sound absorption characteristics for granular materials. Izolacje, No. 9, pp. 26-30.

Sikora J.,Turkiewicz J. 2010, Sound absorption coefficients of granular materials. Mechanics and Control, vol. 29, No. 3, pp. 149-157.

Sikora J., Turkiewicz J. 2011, Granular materials in laminar partitions of noise protection systems. Technical Journal - Mechanics, No.15, pp. 79-92.

Sikora J., Turkiewicz J. 2012, Sound absorbing properties and application of rubber granulates. Izolacje, No. 1, pp. 54-58.

Swift M.J., Bris P., Horoshenkov K.V. 1999, Acoustic absorption in recycled rubber granulate. Applied Acoustics, vol. 57, pp. 203-212. 